\title{
Protocol
}

\section{Purification of Genomic DNA Extracted from Environmental Sources for Use in a Polymerase Chain Reaction}

\author{
Molli M. Newman, Jack W. Feminella, and Mark R. Liles ${ }^{1}$ \\ Department of Biological Sciences, Auburn University, Auburn, AL 36849, USA
}

\section{INTRODUCTION}

The ability to amplify genomic DNA in a polymerase chain reaction (PCR) is dependent upon the purity of the DNA template. Environmental genomic DNA often contains contaminants (e.g., polyphenols, humic acids, polysaccharides) that reduce template purity and can be difficult to remove, thereby inhibiting PCR amplification. There is thus a need for a method to purify extracted genomic DNA without reducing DNA concentration. In this protocol, extracted genomic DNA is embedded in agarose plugs and incubated in a formamide and salt $(\mathrm{NaCl})$ solution to remove contaminants. The $\mathrm{NaCl}$ works to deproteinize and stabilize the DNA. The formamide serves to denature the DNA (which will subsequently be renatured within the agarose plug) and any contaminants that may be bound to the DNA. The purified DNA is extracted from the agarose plug using a standard commercial agarose extraction method, and the DNA may then be used as a template for PCR. Genomic DNA purified using this method has been shown to serve as an efficient template for PCR, without significant loss of DNA yield. An additional advantage of the method is that it allows the simultaneous processing of large numbers of samples at once.

\section{RELATED INFORMATION}

The increase in PCR efficiency using genomic DNA purified by this method is shown in Figure 1. A quantitative PCR was performed using a genomic DNA template purified by this method and the results were compared to those from templates prepared using a commercial kit and other treatment combinations. Liles et al. (2008) have described a method for purifying high-molecular-weight DNA for use in the construction of metagenomic libraries (see also Isolation and Cloning of HighMolecular-Weight Metagenomic DNA from Soil Microorganisms [Liles et al. 2009]). However, the protocol reported here is more rapid and is specifically designed for the purification of genomic DNA to be used as a template for PCR amplification.

\section{MATERIALS}

CAUTIONS AND RECIPES: Please see Appendices for appropriate handling of materials marked with $\langle$ ! $\rangle$, and recipes for reagents marked with $<\mathbf{R}>$.

Reagents

Agarose (molecular biology grade; Fisher Scientific)

Environmental sample of interest

${ }^{1}$ Corresponding author (lilesma@auburn.edu). 
$<!>$ Formamide (deionized, $80 \%[\mathrm{v} / \mathrm{v}]$ in $1.3 \mathrm{M} \mathrm{NaCl}$ )

Store at $4^{\circ} \mathrm{C}$.

Gel extraction kit (e.g., QIAquick Gel Extraction Kit from QIAGEN or Wizard SV Gel and PCR Clean-Up System from Promega)

$\mathrm{NaCl}(1.3 \mathrm{M})$

Reagents for extracting genomic DNA from environmental sample (see Step 1)

$<\mathrm{R}>$ TAE buffer (50X stock)

Dilute to $1 X$ before use.

\section{Equipment}

Beaker (sterile, glass, for preparing soft agarose)

Equipment for extracting genomic DNA from environmental sample (see Step 1)

Microcentrifuge tubes (2-mL)

Micropipettors (p200 and p1000) and tips (200- $\mu \mathrm{L}$ and 1-mL)

Microwave oven

Tube rack

Waterbath preset to $15^{\circ} \mathrm{C}$

\section{METHOD}

\section{Generation of Agarose Plugs and Overnight Incubation}

1. Extract genomic DNA from an environmental sample using a direct extraction method or a commercial kit.

To determine the amount of environmental sample to be processed, follow published methods or the manufacturer's instructions. Typically, commercial kits suggest using $<500 \mathrm{mg}$ of environmental sample for extraction. Note that, even though commercial kits may advertise that "PCR-ready" DNA will be extracted, it is not unusual to obtain samples that cannot be readily used as a PCR template. If, after serial dilution of the DNA template, no PCR product is obtained and the positive controls have been successful, the protocol outlined below may be useful for purifying truly PCR-ready DNA.

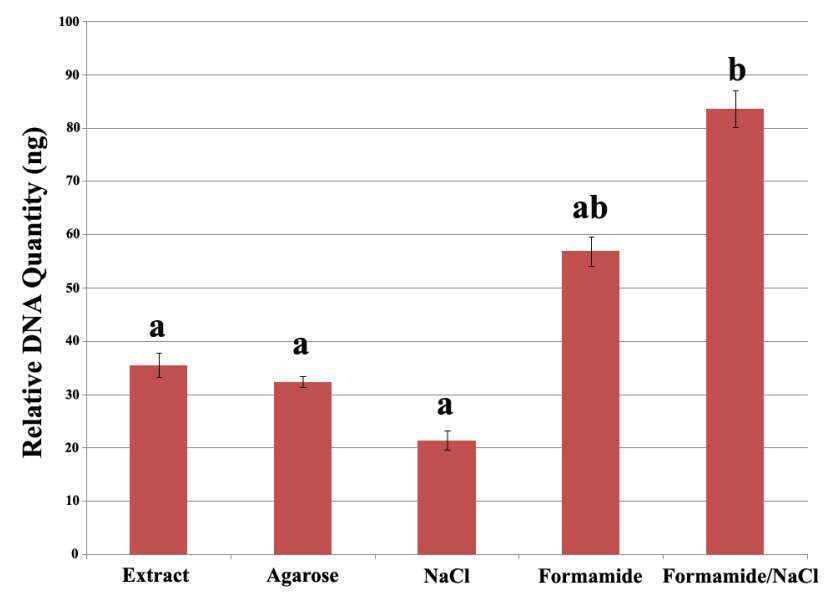

FIGURE 1. Bar graph representing amplified environmental genomic DNA isolated from red maple (Acer rubrum) leaf litter. Genomic DNA was purified using several treatment combinations and gel quantified prior to amplification. A standardized amount of DNA (20 ng) was then used in PCR reactions (domain Bacteria primer set 338F and 518R [Øvreås et al. 1997]) containing a fluorescent probe (SYBR Green; Bio-Rad) that binds to double-stranded DNA, and the fluorescence was measured over time. Final DNA concentration was then calculated by comparing fluorescence of a PCR standard of known DNA concentration to the fluorescence of each sample. All points represent standardized DNA quantity \pm standard error. Letters indicate Tukey's multiple comparison groupings. 
2. Prepare an appropriate volume of $2 \%$ agarose solution in $1 \mathrm{X}$ TAE in a sterile glass beaker. Heat in a microwave oven and let the solution cool to $45^{\circ} \mathrm{C}$. Mix briefly to ensure that the agarose solution is homogenous.

3. Add equal volumes of $2 \%$ agarose solution and DNA extract to a 2-mL microcentrifuge tube. Mix by pipetting up and down briefly using a 1-mL pipette tip.

Typical volumes would be $100 \mu \mathrm{L}$ of $2 \%$ agarose mixed with $100 \mu \mathrm{L}$ of DNA extract. The purpose of embedding the DNA sample in agarose is to allow rapid DNA purification and subsequent washing without the need for DNA precipitation. The agarose provides a matrix for the DNA once it is denatured by the formamide/ $\mathrm{NaCl}$ solution, thereby allowing contaminants to move into the surrounding liquid.

4. Allow the agarose plug to solidify in the microcentrifuge tube at room temperature. This should take $<10 \mathrm{~min}$.

5. Add $5 \mathrm{X}$ volume of a solution of $80 \%$ formamide in $1.3 \mathrm{M} \mathrm{NaCl}$ to the agarose plug. Mix by slowly inverting the tube in a rack.

Formamide denatures the DNA and $\mathrm{NaCl}$ stabilizes it during the incubation. If the total volume of the agarose plug is $200 \mu \mathrm{L}$, add $1 \mathrm{~mL}$ of formamide/ $\mathrm{NaCl}$ solution.

See Troubleshooting.

6. Incubate the samples for $1 \mathrm{~h}$ at $15^{\circ} \mathrm{C}$.

Washing of Agarose Plugs and Extraction of DNA from Agarose

7. Remove the formamide/ $\mathrm{NaCl}$ solution.

8. Wash the agarose plug five times with $1 \mathrm{~mL}$ of $1 \mathrm{X}$ TAE.

9. Extract the DNA from the agarose using a commercial gel extraction kit.

The DNA can now be used for PCR or it can be stored at $-20^{\circ} \mathrm{C}$ or $-85^{\circ} \mathrm{C}$.

See Troubleshooting.

\section{TROUBLESHOOTING}

Problem: The agarose plug remains stuck in the bottom of the microcentrifuge tube.

[Step 5]

Solution: It may be necessary to release the agarose plug from the bottom of the microcentrifuge tube by pressing the pipette tip down the side of the agarose plug. This step will ensure total suspension of the agarose plug in the formamide/ $\mathrm{NaCl}$ solution. Use of a 2-mL microcentrifuge tube during washing steps may prevent this problem.

Problem: The DNA is not sufficiently pure.

[Step 9]

Solution: Consider the following:

1. Depending upon the degree of contamination, the incubation time in Step 6 may be extended to overnight at $15^{\circ} \mathrm{C}$.

2. With highly contaminated samples (i.e., those that change color owing to phenolic or humic contaminants), it may be advisable to remove the formamide/ $\mathrm{NaCl}$ solution during the incubation and replace it with fresh solution.

Problem: The DNA yield is insufficient.

[Step 9]

Solution: Consider the following:

1. During the DNA extraction in Step 9, make sure to follow the manufacturer's recommendations in recovering DNA from the agarose gel.

2. To maximize the yield of DNA recovered from the column, try reducing the volume of the elution buffer (to $\sim 30 \mu \mathrm{L}$ ) and passing the elution buffer over the column two or more times. The only significant loss of DNA during the protocol occurs at this step. 


\section{DISCUSSION}

Several methods exist for the purification of environmental DNA, including those that use phenolchloroform, hexadecyltrimethylammonium bromide (CTAB), polyvinylpolypyrrolidone (PVPP), cesium chloride density centrifugation, and hydroxyapatite column chromatographic purification (for reviews, see Roose-Amsaleg et al. 2001; Robe et al. 2003; see also Ogram et al. 1987; Holben et al. 1988; Knaebel and Crawford 1995). Steffan et al. (1988) have demonstrated that many of these methods (such as those using PVPP, cesium chloride, and hydroxyapatite) lower DNA yield. Often, a combination of two or more purification methods (such as a phenol-chloroform extraction followed by use of $(T A B)$ is required to attain adequate purification of environmental DNA. However, using numerous purification steps not only can decrease DNA yield, but also increases sample-processing time. The latter is particularly disadvantageous when working with large numbers of samples. The protocol described here allows multiple samples to be processed at once.

The purification and amplification of environmental DNA can often be difficult because of low yields and co-isolation of contaminants. Incubation of genomic DNA in agarose plugs during formamide and salt treatment allows removal of contaminants without significant loss of DNA. The protocol described here has been shown to be effective in purifying DNA from various environmental sources, such as soils, leaf litter, and marine corals, which have never successfully provided templates for PCR amplification. Commercial kits for genomic DNA extraction typically shear the DNA, resulting in fragment sizes $<20 \mathrm{~kb}$. The DNA yield obtained using this procedure will vary greatly depending on the initial DNA concentration. After following this procedure, each of the purified DNAs yielded abundant amplicons using $\sim 20$ ng of purified DNA as a template for PCR.

\section{REFERENCES}

Holben WE, Jansson JK, Chelm BK, Tiedje JM. 1988. DNA probe method for the detection of specific microorganisms in the soil bacterial community. Appl Envirnon Microbiol 54: 703-711.

Knaebel DB, Crawford RL. 1995. Extraction and purification of microbial DNA from petroleum-contaminated soils and detection of low numbers of toluene, octane and pesticide degraders by multiplex polymerase chain reaction and Southern analysis. Mol Ecol 4: $579-591$.

Liles MR, Williamson LL, Rodbumrer J, Torsvik V, Goodman RM, Handelsman J. 2008. Recovery, purification, and cloning of highmolecular-weight DNA from soil microorganisms. Appl Environ Microbiol 74: 3302-3305.

Liles MR, Williamson LL, Rodbumrer J, Torsvik V, Parsley LC, Goodman RM, Handelsman J. 2009. Isolation and cloning of high-molecularweight metagenomic DNA from soil microorganisms. Cold Spring
Harb Protoc doi: 10.1101/pdb.prot5271.

Ogram A, Sayler GS, Barkay T. 1987. The extraction and purification of microbial DNA from sediments. J Microbiol Methods 7: 57-66.

Øvreås L, Forney L, Daae FL, Torsvik V. 1997. Distribution of bacterioplankton in meromictic Lake Sælenvannet, as determined by denaturing gradient gel electrophoresis of PCR-amplified gene fragments coding for $16 \mathrm{~S}$ rRNA. Appl Environ Microbiol 63: 3367-3373.

Robe P, Nalin R, Capellano C, Vogel TM, Simonet P. 2003. Extraction of DNA from soil. Eur J Soil Biol 39: 183-190.

Roose-Amsaleg CL, Garnier-Sillam E, Harry M. 2001. Extraction and purification of microbial DNA from soil and sediment samples. Appl Soil Ecol 18: 47-60.

Steffan RJ, Goksøyr J, Bej AK, Atlas RM. 1988. Recovery of DNA from soils and sediments. Appl Environ Microbiol 54: 2908-2915. 


\section{Appendix 1: Recipes}

[NOTE: This print edition of CSH Protocols contains only recipes for reagents requiring multiple components or nonobvious critical steps. Recipes for reagents marked with the $<\mathbf{R}>$ symbol not listed below can be found online at http://www.cshprotocols.org/recipes.]

\section{B\&W buffer $(2 X)$}

$<\mathrm{R}>10 \mathrm{mM}$ Tris-Cl, pH 8.0

$<\mathrm{R}>1$ mM EDTA

$2 \mathrm{M} \mathrm{NaCl}$

\section{Blocking DNA (50X)}

\section{MATERIALS}

\section{Reagents}

DNA from salmon testes (Sigma D1626)

$<\mathrm{R}>\mathrm{TE}(\mathrm{pH} 7.6)$

\section{Equipment}

Heating block preset to $95^{\circ} \mathrm{C}$

Ice

Sonicator

Sterilization filter

\section{METHOD}

1. Dissolve DNA from salmon testes in TE at $5 \mathrm{mg} / \mathrm{mL}$.

2. Shear the DNA by sonication (at medium power) to an average size of $\sim 500-1000 \mathrm{bp}$.

3. Filter-sterilize the solution.

4. Denature the DNA by heating for $15 \mathrm{~min}$ to $95^{\circ} \mathrm{C}$, and rapidly chill on ice.

5. Aliquot the solution into convenient volumes and store at $-20^{\circ} \mathrm{C}$.

\section{BrdU (100X)}

$<$ ! $>$ BrdU (5-bromo-2'-deoxyuridine; Sigma B5002)

$<\mathrm{R}>10 \mathrm{mM}$ Tris- $\mathrm{Cl}(\mathrm{pH} 7.6)$

For a $100 \mathrm{X}$ stock solution, prepare $\mathrm{BrdU}$ at $40 \mathrm{mg} / \mathrm{mL}$ in $10 \mathrm{mM}$ Tris-Cl (pH 7.6) in a 15-mL screw-cap conical tube. Place the solution in a waterbath at $\sim 50^{\circ} \mathrm{C}$ and occasionally vortex vigorously until the BrdU is completely dissolved. Store the solution in convenient (e.g., single-use) aliquots protected from light at $-20^{\circ} \mathrm{C}$. Upon thawing, BrdU may come out of solution and need to be redissolved.

\section{$\mathrm{CaCl}_{2} / \mathrm{MgCl}_{2}$ stock solution}

$<!>\mathrm{CaCl}_{2}(10 \mathrm{mg} / \mathrm{mL})$

$\mathrm{MgCl}_{2}(10 \mathrm{mg} / \mathrm{mL})$

Sterilize by filtration through a $0.45-\mu \mathrm{m}$ nitrocellulose filter. Store at $4^{\circ} \mathrm{C}$. 


\section{Coloration buffer}

\begin{tabular}{lll}
\hline Reagent & Amount to add & Final concentration \\
\hline $1 \mathrm{M} \mathrm{Tris}-\mathrm{HCl}_{1}$ pH 9.5 & $5 \mathrm{~mL}$ & $100 \mathrm{mM}$ \\
$<\mathrm{R}>1 \mathrm{M} \mathrm{MgCl}$ & $2.5 \mathrm{~mL}$ & $50 \mathrm{mM}$ \\
$5 \mathrm{M} \mathrm{NaCl}$ & $1 \mathrm{~mL}$ & $100 \mathrm{mM}$ \\
$20 \%$ Tween 20 (Sigma-Aldrich P1379) & $250 \mu \mathrm{L}$ & $0.1 \%(\mathrm{v} / \mathrm{v})$ \\
$\mathrm{H}_{2} \mathrm{O}$ (sterile) & to $50 \mathrm{~mL}$ &
\end{tabular}

Combine reagents immediately before use. At room temperature, the solution eventually will precipitate.

\section{Detection buffer}

$<\mathrm{R}>100 \mathrm{mM}$ Tris- $\mathrm{Cl}(\mathrm{pH} 9.5)$

$100 \mathrm{mM} \mathrm{NaCl}$

$<\mathrm{R}>50 \mathrm{mM} \mathrm{MgCl}_{2}$

\section{DNA polymerase buffer}

$<\mathrm{R}>10 \mathrm{mM}$ Tris-Cl, $\mathrm{pH} 8.0$

$50 \mathrm{mM} \mathrm{NaCl}$

$10 \mathrm{mM} \mathrm{MgCl}_{2}$

$<$ ! $1 \mathrm{mM}$ DTT (dithiothreitol)

\section{EDTA}

To prepare EDTA at $0.5 \mathrm{M}$ (pH 8.0): Add $186.1 \mathrm{~g}$ of disodium EDTA $2 \mathrm{H}_{2} \mathrm{O}$ to $800 \mathrm{~mL}$ of $\mathrm{H}_{2} \mathrm{O}$. Stir vigorously on a magnetic stirrer. Adjust the $\mathrm{pH}$ to 8.0 with $\mathrm{NaOH}(\sim 20 \mathrm{~g}$ of $\mathrm{NaOH}$ pellets). Dispense into aliquots and sterilize by autoclaving. The disodium salt of EDTA will not go into solution until the $\mathrm{pH}$ of the solution is adjusted to $\sim 8.0$ by the addition of $\mathrm{NaOH}$.

\section{Elution buffer for genomic DNA}

$<\mathrm{R}>\mathrm{TE}(\mathrm{pH} 7.6)$

$<!>1 \%(w / v)$ SDS (sodium dodecyl sulfate)

\section{Formamide}

Deionize the formamide by stirring on a magnetic stirrer with Dowex XG8 mixed bed resin for $1 \mathrm{~h}$ and filtering it twice through Whatman No. 1 paper. Store deionized formamide in small aliquots under nitrogen at $-70^{\circ} \mathrm{C}$.

\section{Germination plates}

$<$ !>Glufosinate ammonium (12 mg/L; Fluka 45520)

$<$ !>Kanamycin $(50 \mathrm{mg} / \mathrm{L})$

$<$ R $>$ MS medium for Arabidopsis (50\%, v/v)

Phytagel (0.25\%, w/v; Sigma-Aldrich P8169)

Prepare a Phytagel stock of $5 \mathrm{~g} / \mathrm{L}$ in $\mathrm{H}_{2} \mathrm{O}$. Autoclave. Cool to $60^{\circ} \mathrm{C}$. Mix the Phytagel stock with an equal volume of MS medium (i.e., to the final concentrations listed above). Add the kanamycin and glufosinate ammonium. Working under a hood, pour into Petri dishes ( $25 \mathrm{~mL}$ per $100-\mathrm{mm}$ plate). 


\section{HEPES-buffered saline (HEBS; 2X)}

Dextrose $(12 \mathrm{mM})$

HEPES (50 mM)

$\mathrm{KCl}(10 \mathrm{mM})$

$\mathrm{NaCl}(280 \mathrm{mM})$

$\mathrm{Na}{ }_{2} \mathrm{HPO}_{4} \cdot 2 \mathrm{H}_{2} \mathrm{O}(1.5 \mathrm{mM})$

Adjust the $\mathrm{pH}$ to 7.05 with $10 \mathrm{~N} \mathrm{NaOH}$; accurate $\mathrm{pH}$ is critical for efficient transfection. Sterilize by filtration through a $0.45-\mu \mathrm{m}$ nitrocellulose filter. Store at $-20^{\circ} \mathrm{C}$.

\section{Hybridization buffer for adult zebrafish}

\begin{tabular}{lll}
\hline Reagent & Amount to add & Final concentration \\
\hline$<$ !> Formamide $(100 \%)$ & $25 \mathrm{~mL}$ & $50 \%$ \\
$<$ !> Heparin $(50 \mathrm{mg} / \mathrm{mL})$ & $50 \mu \mathrm{L}$ & $50 \mu \mathrm{g} / \mathrm{mL}$ \\
$<\mathrm{R}>$ SSC $(20 \mathrm{X})$ & $12.5 \mathrm{~mL}$ & $5 \mathrm{X}$ \\
Torula RNA & $250 \mathrm{mg}$ & $5 \mathrm{mg} / \mathrm{mL}$ \\
Tween 20 (10\%) & $500 \mu \mathrm{L}$ & $0.1 \%$ \\
$\mathrm{H}_{2} \mathrm{O}$ & to $50 \mathrm{~mL}$ & - \\
\hline
\end{tabular}

\section{Immunoprecipitation (IP) buffer for genomic DNA}

$<$ R $>$ PBS for genomic DNA (10X), diluted to $1 \mathrm{X}$

$<!>0.0625 \%(\mathrm{v} / \mathrm{v})$ Triton X-100

\section{LB agar}

$\operatorname{Agar}(20 \mathrm{~g} / \mathrm{L})$

$\mathrm{NaCl}(10 \mathrm{~g} / \mathrm{L} ;$ Sigma-Aldrich S9625)

Tryptone (10 g/L; BD 211705)

Yeast extract (5 g/L; BD 212750)

Add $\mathrm{H}_{2} \mathrm{O}$ to a final volume of $1 \mathrm{~L}$. Adjust the $\mathrm{pH}$ to 7.0 with $5 \mathrm{~N} \mathrm{NaOH}$. Autoclave. Pour into Petri dishes $(\sim 25 \mathrm{~mL}$ per 100-mm plate).

\section{LB-gentamycin agar plates}

Gentamycin, filter-sterilized $(25 \mathrm{mg} / \mathrm{mL}$ stock)

$<$ R $>$ LB agar

Autoclave $1 \mathrm{~L}$ of $\mathrm{LB}$ agar. Cool to $55^{\circ} \mathrm{C}$. Add $1 \mathrm{~mL}$ of the gentamycin stock (i.e., $25 \mathrm{mg}$ ). Pour into Petri dishes ( $25 \mathrm{~mL}$ per 100-mm plate).

\section{LB-gentamycin/kanamycin agar plates}

Gentamycin, filter-sterilized $(25 \mathrm{mg} / \mathrm{mL}$ stock)

$<$ !>Kanamycin, filter-sterilized $(50 \mathrm{mg} / \mathrm{mL}$ stock)

$<$ R $>$ LB agar

Autoclave $1 \mathrm{~L}$ of $\mathrm{LB}$ agar. Cool to $55^{\circ} \mathrm{C}$. Add $1 \mathrm{~mL}$ each of the gentamycin and kanamycin stocks (i.e., 25 and 50 $\mathrm{mg}$, respectively). Pour into Petri dishes ( $25 \mathrm{~mL}$ per $100-\mathrm{mm}$ plate). 


\section{LB (Luria-Bertani) liquid medium}

\begin{tabular}{ll}
\hline Reagent & Amount to add \\
\hline $\mathrm{H}_{2} \mathrm{O}$ & $950 \mathrm{~mL}$ \\
Tryptone & $10 \mathrm{~g}$ \\
$\mathrm{NaCl}$ & $10 \mathrm{~g}$ \\
Yeast extract & $5 \mathrm{~g}$
\end{tabular}

Combine the reagents and shake until the solutes have dissolved. Adjust the $\mathrm{pH}$ to 7.0 with $5 \mathrm{~N} \mathrm{NaOH}(\sim 0.2 \mathrm{~mL})$. Adjust the final volume of the solution to $1 \mathrm{~L}$ with $\mathrm{H}_{2} \mathrm{O}$. Sterilize by autoclaving for $20 \mathrm{~min}$ at $15 \mathrm{psi}\left(1.05 \mathrm{~kg} / \mathrm{cm}^{2}\right)$ on liquid cycle.

$<\mathbf{R}>$ For solid medium, see the recipe entitled "Media containing agar or agarose."

\section{LIDS buffer}

$<\mathrm{R}>10$ mM Tris-Cl, pH 8.0

$<!>1 \%$ lauryl sulfate lithium salt (Sigma)

$<$ R $>100$ mM EDTA

\section{Lysis buffer for genomic DNA}

$<\mathrm{R}>100 \mathrm{mM}$ Tris-Cl $(\mathrm{pH} 8.0)$

$<\mathrm{R}>50 \mathrm{mM}$ EDTA

$<!>1 \%(w / v)$ SDS (sodium dodecyl sulfate)

\section{Media containing agar or agarose}

Prepare liquid media according to the recipe given. Just before autoclaving, add one of the following:

$\begin{array}{ll}\text { Bacto agar (for plates) } & 15 \mathrm{~g} / \mathrm{L} \\ \text { Bacto agar (for top agar) } & 7 \mathrm{~g} / \mathrm{L} \\ \text { Agarose (for plates) } & 15 \mathrm{~g} / \mathrm{L} \\ \text { Agarose (for top agarose) } & 7 \mathrm{~g} / \mathrm{L}\end{array}$

Sterilize by autoclaving for $20 \mathrm{~min}$ at $15 \mathrm{psi}\left(1.05 \mathrm{~kg} / \mathrm{cm}^{2}\right)$ on liquid cycle. When the medium is removed from the autoclave, swirl it gently to distribute the melted agar or agarose evenly throughout the solution. Be careful! The fluid may be superheated and may boil over when swirled. Before adding thermolabile substances (e.g., antibiotics), allow the medium to cool to $50^{\circ} \mathrm{C}-60^{\circ} \mathrm{C}$, and mix the medium by swirling to avoid producing air bubbles.

Before pouring the plates, set up a color code (e.g., two red stripes for LB-ampicillin plates; one black stripe for LB plates, etc.), and mark the edges of the plates with the appropriate colored markers. Pour plates directly from the flask; allow $\sim 30-35 \mathrm{~mL}$ of medium per $90-\mathrm{mm}$ plate. To remove bubbles from the medium in the plate, flame the surface of the medium with a Bunsen burner before the agar or agarose hardens. When the medium has hardened completely, invert the plates and store them at $4^{\circ} \mathrm{C}$ until needed.

The plates should be removed from storage 1-2 $\mathrm{h}$ before they are used. If the plates are fresh, they will "sweat" when incubated at $37^{\circ} \mathrm{C}$. When this condensation drops on the agar/agarose surface, it allows bacterial colonies or bacteriophage plaques to spread and increases the chances of cross-contamination. This problem can be avoided by wiping off the condensation from the lids of the plates and then incubating the plates for several hours at $37^{\circ} \mathrm{C}$ in an inverted position before they are used. Alternatively, remove the liquid by shaking the lid with a single, quick motion. To minimize the possibility of contamination, hold the open plate in an inverted position while removing the liquid from the lid. 


\section{$\mathrm{MgCl}_{2}$ (Magnesium chloride)}

To prepare $1 \mathrm{~L}$ of $1 \mathrm{M} \mathrm{MgCl}_{2^{\prime}}$ dissolve $203.3 \mathrm{~g}$ of $\mathrm{MgCl}_{2} \bullet 6 \mathrm{H}_{2} \mathrm{O}$ in $800 \mathrm{~mL} \mathrm{H} \mathrm{H}_{2}$. Adjust the volume to $1 \mathrm{~L}$ using $\mathrm{H}_{2} \mathrm{O}$. Dispense into aliquots and sterilize by autoclaving.

Note: $\mathrm{MgCl}_{2}$ is extremely hygroscopic. Buy small bottles and do not store opened bottles for long periods of time. Once the crystals become saturated with $\mathrm{H}_{2} \mathrm{O}$, dispose of the chemical properly.

\section{Mono P enzyme solution}

$<!>1 \mathrm{mg} / \mathrm{mL}$ pepsin

$<!>0.1 \mathrm{M}$ acetic acid

$0.5 \mathrm{M} \mathrm{NaCl}$

Alternatively, try enzymes other than pepsin (e.g., DNase), depending on the type of contamination of the Mono P column.

\section{MOPS gel buffer (10X)}

$<$ R $>$ EDTA $(20 \mathrm{mM})$

$<$ ! $>$ MOPS $(200 \mathrm{mM})$

Sodium acetate $(50 \mathrm{mM})$

Adjust pH to 7.0 using $\mathrm{NaOH}$.

\section{MS medium for Arabidopsis}

$4.33 \mathrm{~g}$ Murashige and Skoog basal medium (Sigma M5519)

$20 \mathrm{~g}$ sucrose

Add reagents to $900 \mathrm{~mL}$ of $\mathrm{H}_{2} \mathrm{O}$ and stir until dissolved. Adjust the $\mathrm{pH}$ to 5.7 with $2 \mathrm{~N} \mathrm{KOH}$. Adjust the final volume to $1 \mathrm{~L}$ with $\mathrm{H}_{2} \mathrm{O}$. Sterilize by filtration at room temperature.

\section{NEB buffer 2 for washes (1X)}

$50 \mathrm{mM} \mathrm{NaCl}$

$<\mathrm{R}>10 \mathrm{mM}$ Tris-Cl

$10 \mathrm{mM} \mathrm{MgCl}$

$<$ !>1 mM DTT (dithiothreitol)

Adjust $\mathrm{pH}$ to 7.9 .

PBS for genomic DNA (10X)

\begin{tabular}{lll}
\hline Reagent & Quantity (for 1 L) & Final concentration (10X) \\
\hline $\mathrm{NaCl}$ & $80 \mathrm{~g}$ & $1.37 \mathrm{M}$ \\
$\mathrm{KCl}$ & $2 \mathrm{~g}$ & $27 \mathrm{mM}$ \\
$\mathrm{Na}_{2} \mathrm{HPO}_{4} \cdot 7 \mathrm{H}_{2} \mathrm{O}$ & $11.5 \mathrm{~g}$ & $43 \mathrm{mM}$ \\
$\mathrm{KH}_{2} \mathrm{PO}_{4}$ & $1.9 \mathrm{~g}$ & $14 \mathrm{mM}$ \\
$\mathrm{H}_{2} \mathrm{O}$ & to $1 \mathrm{~L}$ &
\end{tabular}

Adjust the $\mathrm{pH}$ to 7.4 and sterilize by autoclaving. 
Phosphate-buffered saline (PBS)

\begin{tabular}{lllll}
\hline Reagent & $\begin{array}{l}\text { Amount to add } \\
\text { (for 1X solution) }\end{array}$ & $\begin{array}{l}\text { Final concentration } \\
(1 \mathrm{X})\end{array}$ & $\begin{array}{l}\text { Amount to add } \\
\text { (for 10X stock) }\end{array}$ & $\begin{array}{l}\text { Final concentration } \\
(10 \mathrm{X})\end{array}$ \\
\hline $\mathrm{NaCl}$ & $8 \mathrm{~g}$ & $137 \mathrm{mM}$ & $80 \mathrm{~g}$ & $1.37 \mathrm{M}$ \\
$<!>\mathrm{KCl}$ & $0.2 \mathrm{~g}$ & $2.7 \mathrm{mM}$ & $2 \mathrm{~g}$ & $27 \mathrm{mM}$ \\
$\mathrm{Na}_{2} \mathrm{HPO}_{4}$ & $1.44 \mathrm{~g}$ & $10 \mathrm{mM}$ & $14.4 \mathrm{~g}$ & $100 \mathrm{mM}$ \\
$\mathrm{KH}_{2} \mathrm{PO}_{4}$ & $0.24 \mathrm{~g}$ & $1.8 \mathrm{mM}$ & $2.4 \mathrm{~g}$ & $18 \mathrm{mM}$
\end{tabular}

If necessary, $\mathrm{PBS}$ may be supplemented with the following:

$\begin{array}{lllll}<!>\mathrm{CaCl}_{2} \cdot 2 \mathrm{H}_{2} \mathrm{O} & 0.133 \mathrm{~g} & 1 \mathrm{mM} & 1.33 \mathrm{~g} & 10 \mathrm{mM} \\ <!>\mathrm{MgCl}_{2} \cdot 6 \mathrm{H}_{2} \mathrm{O} & 0.10 \mathrm{~g} & 0.5 \mathrm{mM} & 1.0 \mathrm{~g} & 5 \mathrm{mM}\end{array}$

$<$ !> PBS can be made as a $1 \mathrm{X}$ solution or as a $10 \mathrm{X}$ stock. To prepare $1 \mathrm{~L}$ of either $1 \mathrm{X}$ or $10 \mathrm{X}$ PBS, dissolve the reagents listed above in $800 \mathrm{~mL}$ of $\mathrm{H}_{2} \mathrm{O}$. Adjust the $\mathrm{pH}$ to 7.4 (or 7.2, if required) with $\mathrm{HCl}$, and then add $\mathrm{H}_{2} \mathrm{O}$ to $1 \mathrm{~L}$. Dispense the solution into aliquots and sterilize them by autoclaving for $20 \mathrm{~min}$ at $15 \mathrm{psi}$ $\left(1.05 \mathrm{~kg} / \mathrm{cm}^{2}\right)$ on liquid cycle or by filter sterilization. Store PBS at room temperature.

\section{PTW buffer}

Tween 20

$<$ R $>$ PBS

Dissolve $0.1 \%(v / v)$ Tween 20 in PBS.

\section{RNA denaturing buffer}

\begin{tabular}{ll}
\hline Reagent & Amount to add (for $250 \mu \mathrm{L})$ \\
\hline$<$ ! $>$ Formaldehyde (37\%) & $40 \mu \mathrm{L}$ \\
$<\mathrm{R}><$ ! $>$ Formamide, deionized & $134 \mu \mathrm{L}$ \\
$<\mathrm{R}>$ MOPS gel buffer (10X) & $36 \mu \mathrm{L}$ \\
$\mathrm{H}_{2} \mathrm{O}$ & $40 \mu \mathrm{L}$ \\
\hline
\end{tabular}

\section{RNA gel-loading dye (4X)}

\begin{tabular}{ll}
\hline Reagent & Amount to add (for $80 \mu \mathrm{L})$ \\
\hline$<!>$ Bromophenol blue $(0.2 \%)$ & $7.5 \mu \mathrm{L}$ \\
Sucrose (50\%) & $64 \mu \mathrm{L}$ \\
$\mathrm{H}_{2} \mathrm{O}$ & $8.5 \mu \mathrm{L}$ \\
\hline
\end{tabular}

\section{RNA gel-running buffer}

\begin{tabular}{ll}
\hline Reagent & Amount to add (for 1.5 L) \\
\hline$<$ !> Formaldehyde (37\%) & $300 \mathrm{~mL}$ \\
$<$ R $>$ MOPS gel buffer (10X) & $150 \mathrm{~mL}$ \\
Water & $1050 \mathrm{~mL}$ \\
\hline
\end{tabular}

\section{RSB buffer}

$<$ R>10 mM Tris-Cl, pH 7.4

$10 \mathrm{mM} \mathrm{NaCl}$

$3 \mathrm{mM} \mathrm{MgCl}_{2}$ 


\section{Selection plates for transgenic Arabidopsis}

Bacto agar $(7 \mathrm{~g} / \mathrm{L})$

$<!>$ Carbenicillin $(500 \mathrm{mg} / \mathrm{L})$

$<$ !>Clufosinate ammonium (12 mg/L)

$<$ !>Kanamycin $(50 \mathrm{mg} / \mathrm{L})$

$<\mathrm{R}>\mathrm{MS}$ medium for Arabidopsis (50\%, v/v)

Prepare a bacto agar stock of $14 \mathrm{~g} / \mathrm{L}$. Autoclave. Cool to $60^{\circ} \mathrm{C}$. Mix with an equal volume of MS medium (i.e., to the final concentrations listed above). Add the antibiotics and glufosinate ammonium. Mix well. Working under a hood, pour into Petri dishes ( $25 \mathrm{~mL}$ per 100-mm plate).

$<$ !>Carbenicillin inhibits growth of Agrobacterium. Alternatively, use $100 \mathrm{mg} / \mathrm{L}$ cefotaxime.

\section{SSC}

For a $20 \mathrm{X}$ solution: Dissolve $175.3 \mathrm{~g}$ of $\mathrm{NaCl}$ and $88.2 \mathrm{~g}$ of sodium citrate in $800 \mathrm{~mL}$ of $\mathrm{H}_{2} \mathrm{O}$. Adjust the $\mathrm{pH}$ to 7.0 with a few drops of a $14 \mathrm{~N}$ solution of $\mathrm{HCl}$. Adjust the volume to $1 \mathrm{~L}$ with $\mathrm{H}_{2} \mathrm{O}$. Dispense into aliquots. Sterilize by autoclaving. The final concentrations of the ingredients are $3.0 \mathrm{M} \mathrm{NaCl}$ and $0.3 \mathrm{M}$ sodium citrate.

\section{SSC (3X)}

$0.45 \mathrm{M} \mathrm{NaCl}$

$45 \mathrm{mM}$ sodium citrate

Adjust to $\mathrm{pH} 7.0$ with $\mathrm{HCl}$. Filter-sterilize.

\section{Stripping buffer}

$<\mathbf{R}><$ ! $>$ Formamide, deionized $(50 \%)$

$<$ ! $>$ SDS (sodium dodecyl sulfate; $1 \%$ )

$<\mathrm{R}>\operatorname{SSC}(0.1 \mathrm{X})$

\section{TBE buffer $(0.5 \mathrm{X})$}

$<$ R $>40$ mM Tris-Cl, pH 8.3

$<$ ! $>45 \mathrm{mM}$ boric acid

$<\mathrm{R}>1$ mM EDTA

\section{$\operatorname{TBS}(Z)$}

$<\mathrm{R}>100$ mM Tris- $\mathrm{Cl}(\mathrm{pH} 7.5)$

$150 \mathrm{mM} \mathrm{NaCl}$

\section{TD buffer}

\begin{tabular}{ll}
\hline Reagent & Quantity $(\mathrm{g} / \mathrm{L})$ \\
\hline$<!>\mathrm{KCl}$ & 0.38 \\
$\mathrm{Na}_{2} \mathrm{HPO}_{4} \cdot 7 \mathrm{H}_{2} \mathrm{O}$ & 0.1 \\
$\mathrm{NaCl}$ & 8.0 \\
$<!>$ Tris & 3.0
\end{tabular}

Adjust the $\mathrm{pH}$ to 7.4. Sterilize by autoclaving. 


\section{TE buffer}

\begin{tabular}{lll}
\hline Reagent & Quantity (for $100 \mathrm{~mL}$ ) & Final concentration \\
\hline$<\mathrm{R}>$ EDTA $(0.5 \mathrm{M}, \mathrm{pH} 8.0)$ & $0.2 \mathrm{~mL}$ & $1 \mathrm{mM}$ \\
$<\mathrm{R}>$ Tris-Cl $(1 \mathrm{M}, \mathrm{pH} 8.0)$ & $1 \mathrm{~mL}$ & $10 \mathrm{mM}$ \\
$\mathrm{H}_{2} \mathrm{O}$ & to $100 \mathrm{~mL}$ & \\
\hline
\end{tabular}

\section{TE (pH 7.6)}

$<\mathrm{R}>10 \mathrm{mM}$ Tris- $\mathrm{Cl}(\mathrm{pH} 7.6)$

$<$ R $>1$ mM EDTA

Sterilize by autoclaving.

\section{Tris-buffered saline (TBS) for yeast}

$<\mathrm{R}>100 \mathrm{mM}$ Tris- $\mathrm{Cl}(\mathrm{pH} 7.6)$

$150 \mathrm{mM} \mathrm{NaCl}$

Sterilize by autoclaving.

\section{Tris-Cl}

$<$ ! $>$ Tris base

$<!>\mathrm{HCl}$

To prepare a $1 \mathrm{M}$ solution, dissolve $121.1 \mathrm{~g}$ of Tris base in $800 \mathrm{~mL}$ of $\mathrm{H}_{2} \mathrm{O}$. Adjust the $\mathrm{pH}$ to the desired value by adding concentrated $\mathrm{HCl}$.

\begin{tabular}{ll}
$\mathrm{pH}$ & $\mathrm{HCl}$ \\
\hline 7.4 & $70 \mathrm{~mL}$ \\
7.6 & $60 \mathrm{~mL}$ \\
8.0 & $42 \mathrm{~mL}$
\end{tabular}

Allow the solution to cool to room temperature before making final adjustments to the $\mathrm{pH}$. Adjust the volume of the solution to $1 \mathrm{~L}$ with $\mathrm{H}_{2} \mathrm{O}$. Dispense into aliquots and sterilize by autoclaving.

If the $1 \mathrm{M}$ solution has a yellow color, discard it and obtain Tris of better quality. The $\mathrm{pH}$ of Tris solutions is temperature-dependent and decreases $\sim 0.03 \mathrm{pH}$ units for each $1^{\circ} \mathrm{C}$ increase in temperature. For example, a $0.05 \mathrm{M}$ solution has $\mathrm{pH}$ values of $9.5,8.9$, and 8.6 at $5^{\circ} \mathrm{C}, 25^{\circ} \mathrm{C}$, and $37^{\circ} \mathrm{C}$, respectively.

\section{Yeast extract-peptone-dextrose growth medium (YEPD)}

\begin{tabular}{lll} 
Reagent & Quantity (for 1 L) & Final concentration (w/v) \\
\hline Bacto peptone & $20 \mathrm{~g}$ & $2 \%$ \\
Yeast extract & $10 \mathrm{~g}$ & $1 \%$ \\
Dextrose & $20 \mathrm{~g}$ & $2 \%$ \\
$\mathrm{H}_{2} \mathrm{O}$ & to $1 \mathrm{~L}$ & \\
Sterilize by autoclaving. & \\
\hline
\end{tabular}




\section{Appendix 2: Cautions}

[NOTE: For reagents marked with the $<!>$ symbol not listed below, please consult the manufacturer's Material Safety Data Sheet for further information. Researchers using the procedures in these protocols contained in this issue of CSH Protocols do so at their own risk. Cold Spring Harbor Laboratory makes no representations or warranties with respect to the material set forth in these protocols and has no liability in connection with the use of these materials. Materials used in these protocols may be considered hazardous and should be used with caution.]

1-Methylimidazole is highly corrosive and causes burns. It is harmful by inhalation, ingestion, or skin absorption. Wear appropriate gloves and safety goggles and use only in a chemical fume hood.

1-Methylpiperazine is highly flammable, combustible, and causes burns. It may be harmful by inhalation, ingestion, or skin absorption. Wear appropriate gloves and safety glasses. Do not breathe the dust. Keep away from heat, sparks, and open flame.

$\left[\alpha^{32} \mathrm{P}\right] \mathrm{dCTP}$ is a radioactive substance. When planning an experiment that involves the use of radioactivity, consider the physico-chemical properties of the isotope (half-life, emission type, and energy), the chemical form of the radioactivity, its radioactive concentration (specific activity), total amount, and its chemical concentration. Order and use only as much as needed. Always wear appropriate gloves, lab coat, and safety goggles when handling radioactive material. $X$ rays and gamma rays are electromagnetic waves of very short wavelengths either generated by technical devices or emitted by radioactive materials. They might be emitted isotropically from the source or may be focused into a beam. Their potential dangers depend on the time period of exposure, the intensity experienced, and the wavelengths used. Be aware that appropriate shielding is usually made of lead or other similar material. The thickness of the shielding is determined by the energy(s) of the $X$ rays or gamma rays. Consult the local safety office for further guidance in the appropriate use and disposal of radioactive materials. Always monitor thoroughly after using radioisotopes. A convenient calculator to perform routine radioactivity calculations can be found at http://www.graphpad.com/calculators/radcalc.cfm.

Acetic acid (concentrated) must be handled with great care. It may be harmful by inhalation, ingestion, or skin absorption. Wear appropriate gloves and goggles. Use in a chemical fume hood.

BCIP (5-Bromo-4-chloro-3-indolyl-phosphate) is an irritant and may be harmful by inhalation, ingestion, or skin absorption. Wear appropriate gloves and safety glasses. Do not breathe the dust.

Boric acid $\left(\mathrm{H}_{3} \mathrm{BO}_{3}\right)$ may be harmful by inhalation, ingestion, or skin absorption. Wear appropriate gloves and goggles.
BrdU (Bromodeoxyuridine, 5-Bromo-2'-deoxyuridine, 5Bromodeoxyuridine) is a mutagen. It may be harmful by inhalation, ingestion, or skin absorption. It may cause irritation. Avoid breathing the dust. Wear appropriate gloves and safety glasses and always use in a chemical fume hood.

Bromophenol blue may be harmful by inhalation, ingestion, or skin absorption. Wear appropriate gloves and safety glasses and use in a chemical fume hood.

$\mathrm{CaCl}_{2}$ (Calcium chloride) is hygroscopic and may cause cardiac disturbances. It may be harmful by inhalation, ingestion, or skin absorption. Do not breathe the dust. Wear appropriate gloves and safety goggles.

Carbenicillin may cause sensitization by inhalation, ingestion, or skin absorption. Wear appropriate gloves and safety glasses.

Cefotaxime may cause allergic reactions. It may be harmful by inhalation, ingestion, or skin absorption Wear appropriate gloves and safety goggles and always use in a chemical fume hood. Do not breathe the dust.

Chloroform $\left(\mathrm{CHCl}_{3}\right)$ is irritating to the skin, eyes, mucous membranes, and respiratory tract. It is a carcinogen and may damage the liver and kidneys. It is also volatile. Avoid breathing the vapors. Wear appropriate gloves and safety glasses. Always use in a chemical fume hood.

Chloroquine may be harmful by inhalation, ingestion, or skin absorption. Prolonged exposure can lead to permanent eye damage. Wear appropriate gloves and safety goggles.

DEAE (Diethylaminoethanol) may be harmful by inhalation, ingestion, or skin absorption. Wear appropriate gloves and safety glasses and use in a chemical fume hood.

Diethanolamine may be harmful by inhalation, ingestion, or skin absorption. Wear appropriate gloves and safety glasses.

Doxycycline is an irritant and may be harmful by inhalation, ingestion, or skin absorption. Wear appropriate gloves and safety glasses. Do not breathe the dust.

Dry ice (Carbon dioxide; $\mathrm{CO}_{2}$ ) $\mathrm{CO}_{2}$ (carbon dioxide; dry ice) in all forms may be fatal by inhalation, ingestion, or skin 
absorption. In high concentrations, it can paralyze the respiratory center and cause suffocation. Use only in wellventilated areas. In the form of dry ice, contact with carbon dioxide can also cause frostbite. Do not place large quantities of dry ice in enclosed areas such as cold rooms. Wear appropriate gloves and safety goggles.

DTT (Dithiothreitol) is a strong reducing agent that emits a foul odor. It may be harmful by inhalation, ingestion, or skin absorption. When working with the solid form or highly concentrated stocks, wear appropriate gloves and safety glasses and use in a chemical fume hood.

Ethanolamine $\left(\mathrm{HOCH}_{2} \mathrm{CH}_{2} \mathrm{NH}_{2}\right)$ is toxic and harmful by inhalation, ingestion, or skin absorption. Handle with care and avoid any contact with the skin. Wear appropriate gloves and goggles. Use in a chemical fume hood. Ethanolamine is highly corrosive and reacts violently with acids.

Ethidium bromide is a powerful mutagen and is toxic. Consult the local institutional safety officer for specific handling and disposal procedures. Avoid breathing the dust. Wear appropriate gloves when working with solutions that contain this dye.

Formaldehyde ( $\mathrm{HCOH})$ is highly toxic and volatile. It is also a carcinogen. It is readily absorbed through the skin and is irritating or destructive to the skin, eyes, mucous membranes, and upper respiratory tract. Avoid breathing the vapors. Wear appropriate gloves and safety glasses. Always use in a chemical fume hood. Keep away from heat, sparks, and open flame.

Formamide is teratogenic. The vapor is irritating to the eyes, skin, mucous membranes, and upper respiratory tract. It may be harmful by inhalation, ingestion, or skin absorption. Wear appropriate gloves and safety glasses. Always use in a chemical fume hood when working with concentrated solutions of formamide. Keep working solutions covered as much as possible.

Glufosinate ammonium may be harmful by inhalation, ingestion, or skin absorption. Wear respirator, appropriate gloves, and safety glasses. Do not breathe the dust.

$\mathrm{HCl}$ (Hydrochloric acid, Hydrochloride) is volatile and may be fatal if inhaled, ingested, or absorbed through the skin. It is extremely destructive to mucous membranes, upper respiratory tract, eyes, and skin. Wear appropriate gloves and safety glasses. Use with great care in a chemical fume hood. Wear goggles when handling large quantities.

Heparin is an irritant and may act as an anticoagulant subcutaneously or intravenously. It may be harmful by inhalation, ingestion, or skin absorption. Wear appropriate gloves and safety glasses.

Hoechst 33342 (sometimes called bisbenzimide) may be harmful by inhalation, ingestion, or skin absorption. Wear appropriate gloves and safety glasses and use in a chemical fume hood. Do not breathe the dust.
IGEPAL CA-630 is a possible carcinogen and can cause severe damage to the eyes. It may be harmful by inhalation, ingestion, or skin absorption. Wear appropriate gloves and safety glasses and use in a chemical fume hood. Do not breathe the vapor.

Imidazole is corrosive and may be harmful by inhalation, ingestion, or skin absorption. Wear appropriate gloves and safety glasses and use in a chemical fume hood.

Iminodiacetic acid is an irritant and may be harmful by inhalation, ingestion, or skin absorption. Wear appropriate gloves and safety goggles. Do not breathe the dust.

Kanamycin may be harmful by inhalation, ingestion, or skin absorption. Wear appropriate gloves and safety glasses. Use only in a well-ventilated area.

$\mathrm{KCl}$ (Potassium chloride) may be harmful by inhalation, ingestion, or skin absorption. Wear appropriate gloves and safety glasses.

Lauryl sulfate lithium salt (Lithium dodecyl sulfate) may be harmful by ingestion, inhalation, or skin absorption. Wear appropriate gloves when weighing and use in a chemical fume hood.

Liquid nitrogen $\left(\mathrm{LN}_{2}\right)$ can cause severe damage due to its extreme temperature. Handle frozen samples with extreme caution. Do not breathe the vapors. Seepage of liquid nitrogen into frozen vials that are immersed in liquid nitrogen can cause the vials to explode when they are removed. Use vials with O-rings when possible. Wear cryo-mitts and a face mask. Do not allow the liquid nitrogen to spill onto clothing. Do not breathe the vapors.

Methanol ( $\mathrm{MeOH}, \mathrm{H}_{3} \mathrm{COH}$ ) is poisonous and can cause blindness. It may be harmful by inhalation, ingestion, or skin absorption. Adequate ventilation is necessary to limit exposure to vapors. Avoid inhaling these vapors. Wear appropriate gloves and goggles. Use only in a chemical fume hood.

$\mathrm{MgCl}_{2}$ (Magnesium chloride) may be harmful by inhalation, ingestion, or skin absorption. Wear appropriate gloves and safety glasses and use in a chemical fume hood.

MOPS (3-[N-Morpholino]-propanesulfonic acid) may be harmful by inhalation, ingestion, or skin absorption. It is irritating to mucous membranes and upper respiratory tract. Wear appropriate gloves and safety glasses. Use in a chemical fume hood.

$\mathrm{NaOH}$ (Sodium hydroxide) and solutions containing $\mathrm{NaOH}$ are highly toxic and caustic and should be handled with great care. Wear appropriate gloves and a face mask. All concentrated bases should be handled in a similar manner.

NBT (4-Nitro blue tetrazolium chloride) may be harmful by inhalation, ingestion, or skin absorption. Wear appropriate gloves and safety glasses. 
Paraformaldehyde is highly toxic and may be fatal. It may be a carcinogen. It is readily absorbed through the skin and is extremely destructive to the skin, eyes, mucous membranes, and upper respiratory tract. Avoid breathing the dust or vapor. Wear appropriate gloves and safety glasses and use in a chemical fume hood. Keep away from heat, sparks, and open flame.

Pepsin may be harmful by inhalation, ingestion, or skin absorption. Wear appropriate gloves and safety glasses.

Phenol is extremely toxic, highly corrosive, and can cause severe burns. It may be harmful by inhalation, ingestion, or skin absorption. Wear appropriate gloves, goggles, and protective clothing. Always use in a chemical fume hood. Rinse any areas of skin that come in contact with phenol with a large volume of water and wash with soap and water; do not use ethanol!

Phenol:chloroform:isoamyl alcohol Phenol is extremely toxic, highly corrosive, and can cause severe burns. It may be harmful by inhalation, ingestion, or skin absorption. Wear appropriate gloves, goggles and protective clothing. Always use in a chemical fume hood. Rinse any areas of skin that come in contact with phenol with a large volume of water and wash with soap and water; do not use ethanol!

Chloroform $\left(\mathrm{CHCl}_{3}\right)$ is irritating to the skin, eyes, mucous membranes, and respiratory tract. It is a carcinogen and may damage the liver and kidneys. It is also volatile. Avoid breathing the vapors. Wear appropriate gloves and safety glasses. Always use in a chemical fume hood.

Isoamyl alcohol may be harmful by inhalation, ingestion, or skin absorption and presents a risk of serious damage to the eyes. Wear appropriate gloves and safety goggles. Keep away from heat, sparks, and open flame.

Piperazine is corrosive and causes burns. It is also extremely destructive to the tissue of the mucus membranes and upper respiratory tract, eyes, and skin. It is be harmful by inhalation, ingestion, or skin absorption. Wear appropriate gloves and safety glasses and use only in a chemical fume hood. Do not breathe the dust.

Proteinase $\mathbf{K}$ is an irritant and may be harmful by inhalation, ingestion, or skin absorption. Wear appropriate gloves and safety glasses.

RNase $\mathbf{A}$ is an irritant and may be harmful by inhalation, ingestion, or skin absorption. Wear appropriate gloves and safety glasses. Do not breathe the dust.

S-Adenosylmethionine is toxic and may be harmful by inhalation, ingestion, or skin absorption. Wear appropriate gloves and safety glasses. Use in a chemical fume hood. Do not breathe the dust.

SDS (Sodium dodecyl sulfate) is toxic, an irritant, and poses a risk of severe damage to the eyes. It may be harmful by inhalation, ingestion, or skin absorption. Wear appropriate gloves and safety goggles. Do not breathe the dust.
Silwet L-77 (also known as "Vac-in-Stuff") may be harmful by inhalation, ingestion, or skin absorption. Wear appropriate gloves and safety goggles. Do not inhale the aerosol.

Sodium azide $\left(\mathrm{NaN}_{3}\right)$ is highly poisonous. It blocks the cytochrome electron transport system. Solutions containing sodium azide should be clearly marked. It may be harmful by inhalation, ingestion, or skin absorption. Wear appropriate gloves and safety goggles and handle it with great care. Sodium azide is an oxidizing agent and should not be stored near flammable chemicals.

Sodium hypochlorite ( $\mathrm{NaOCl}$, Bleach) is poisonous, can be explosive, and may react with organic solvents. It may be fatal by inhalation and is also harmful by ingestion and destructive to the skin. Wear appropriate gloves and safety glasses and use in a chemical fume hood to minimize exposure and odor.

Sodium sulfate $\left(\mathrm{Na}_{2} \mathrm{SO}_{4}\right)$ may be harmful by inhalation, ingestion, or skin absorption. Wear appropriate gloves and safety glasses and use in a chemical fume hood.

Tricaine (Tricaine methanesulfonate) is an irritant and may be harmful by inhalation, ingestion, or skin absorption. Wear appropriate gloves and safety glasses.

Triethanolamine (TEA) may be harmful by inhalation, ingestion, or skin absorption. Wear appropriate gloves and safety glasses and use only in a chemical fume hood.

Triethylamine (TEN) is highly toxic and flammable. It is extremely corrosive to the mucous membranes, upper respiratory tract, eyes, and skin. It may be harmful by inhalation, ingestion, or skin absorption. Wear appropriate gloves and safety glasses and use in a chemical fume hood. Keep away from heat, sparks, and open flame.

Trifluoroacetic acid (TFA) may be harmful by inhalation, ingestion, or skin absorption. Concentrated acids must be handled with great care. Decomposition causes toxic fumes. Wear appropriate gloves and a face mask. Use in a chemical fume hood.

Tris may be harmful by inhalation, ingestion, or skin absorption. Wear appropriate gloves and safety glasses.

Tris base may be harmful by inhalation, ingestion, or skin absorption. Wear appropriate gloves and safety glasses.

Triton X-100 causes severe eye irritation and burns. It may be harmful by inhalation, ingestion, or skin absorption. Wear appropriate gloves and safety goggles.

Trypan blue may be a carcinogen and may be harmful by inhalation, ingestion, or skin absorption. Do not breathe the dust. Wear appropriate gloves and safety glasses.

Trypsin may cause an allergic respiratory reaction. It may be harmful by inhalation, ingestion, or skin absorption. Do not 
breathe the dust. Wear appropriate gloves and safety goggles. Use with adequate ventilation.

UV light and/or UV radiation is dangerous and can damage the retina of the eyes. Never look at an unshielded UV light source with naked eyes. Examples of UV light sources that are common in the laboratory include handheld lamps and transilluminators. View only through a filter or safety glasses that absorb harmful wavelengths. UV radiation is also mutagenic and carcinogenic. To minimize exposure, make sure that the UV light source is adequately shielded. Wear protective appropriate gloves when holding materials under the UV light source. 